IZA DP No. 4444

Atypical Work: Who Gets It, and Where Does It Lead? Some U.S. Evidence Using the NLSY79

John T. Addison

Chad Cotti

Christopher J. Surfield

September 2009 


\title{
Atypical Work: Who Gets It, and Where Does It Lead? Some U.S. Evidence Using the NLSY79
}

\author{
John T. Addison \\ University of South Carolina, \\ Queen's University Belfast and IZA \\ Chad Cotti \\ University of Wisconsin Oshkosh \\ Christopher J. Surfield \\ Saginaw Valley State University
}

\author{
Discussion Paper No. 4444 \\ September 2009
}

\author{
IZA \\ P.O. Box 7240 \\ 53072 Bonn \\ Germany \\ Phone: +49-228-3894-0 \\ Fax: +49-228-3894-180 \\ E-mail: iza@iza.org
}

\begin{abstract}
Any opinions expressed here are those of the author(s) and not those of IZA. Research published in this series may include views on policy, but the institute itself takes no institutional policy positions.

The Institute for the Study of Labor (IZA) in Bonn is a local and virtual international research center and a place of communication between science, politics and business. IZA is an independent nonprofit organization supported by Deutsche Post Foundation. The center is associated with the University of Bonn and offers a stimulating research environment through its international network, workshops and conferences, data service, project support, research visits and doctoral program. IZA engages in (i) original and internationally competitive research in all fields of labor economics, (ii) development of policy concepts, and (iii) dissemination of research results and concepts to the interested public.
\end{abstract}

IZA Discussion Papers often represent preliminary work and are circulated to encourage discussion. Citation of such a paper should account for its provisional character. A revised version may be available directly from the author. 
IZA Discussion Paper No. 4444

September 2009

\title{
ABSTRACT \\ Atypical Work: Who Gets It, and Where Does It Lead? Some U.S. Evidence Using the NLSY79
}

\begin{abstract}
Atypical work arrangements have long been criticized as offering more precarious and lower paid work than regular open-ended employment. In an important paper, Booth et al. (2002) were among the first to recognize that notwithstanding their potential deficiencies, such jobs also functioned as a stepping stone to permanent work. This conclusion proved prescient and has received increasing support in Europe. In the present note, we provide a parallel analysis to Booth et al. for the United States - somewhat of a missing link in the evolving empirical literature - and obtain not dissimilar similar findings for the category of temporary workers as do they for fixed-term contract workers.
\end{abstract}

JEL Classification: J30, J40, J63

Keywords: atypical work, temporary jobs, contracting/consulting work, regular open-ended employment, earnings development

Corresponding author:

John T. Addison

Department of Economics

Moore School of Business

University of South Carolina

1705 College Street

Columbia, SC 29208

USA

E-mail: ecceaddi@moore.sc.edu 


\section{Introduction}

Atypical work, as its name implies, has often been looked upon with disfavour by economists in terms of the remuneration and career possibilities attaching to temporary work of this nature. Indeed, in their introduction to the Economic Journal symposium on temporary jobs, Booth, Dolado, and Frank (2002) summarize the thrust of the contributions as suggesting that the expansion of temporary jobs as a way of increasing labour market flexibility may be undesirable. Yet in analyzing the British evidence, Booth, Francesconi, and Frank (2002) while still concluding that temporary jobs are not desirable vis-à-vis open-ended employment temper this judgment with evidence that the main work form they examine - fixed-term contracts - does provide a stepping stone to regular employment and carries no long term wage disadvantage for women who start off their careers in fixed-term employment.

Since the symposium, the stepping-stones counter argument has if anything gathered force (e.g. Freier and Steiner, 2008; García-Pérez and Muñoz-Bullón. 2003; Ichino, Mealli and Nannicini, 2004, 2008; Kvasnika, 2008; Portugal and Varajão, 2009; Zijl, van den Berg, and Heyma, 2004). That said, the shifting evidence did not dissuade the EU from passing the long-delayed third and 'final' piece of atypical worker legislation in November 2008 covering temporary agency work. ${ }^{1}$ Under Directive 2008/104/EC, the basic working conditions of temporary agency workers are for the duration of their assignment at the user undertaking to be at least equal to those that would obtain had they been recruited directly into that job by the undertaking (Official Journal, 2008). This equal treatment principle is to apply from the first day of an assignment unless otherwise amended on the basis of agreement between organized labour and capital (so that the qualifying period is 12 weeks in the case of the United Kingdom). ${ }^{2}$

Something of a stand-out in the modern literature is the U.S. evidence, which is less developed than its European counterpart and mentioned only en passant in the symposium. ${ }^{3}$ Yet we can use data from the National Longitudinal Survey of Youth, 1979 Cohort (NLSY79) to broadly replicate Booth, Francesconi, and Frank's (2002) wage and duration analysis (if not their evaluation of job satisfaction), and provide a useful point of contact between the two literatures regarding career prospects. We shall provide evidence on two categories of atypical workers: temporary workers, comprising temporary agency 
workers and direct hire temps, and the composite group of contractors/consultants. Temporary workers merit special attention in the wake of the recent EU legislation while contractors/consultants are of interest because of their earning a wage premium. As we shall see, our results for the former category fairly closely accord with those of Booth, Francesconi, and Frank.

\section{Data}

The NLSY79 first began asking workers about their type of working arrangements in 1994. The 1994 survey also contains data on the current job as well as retrospective data on the last four jobs held up to then. The questions on working arrangement were thence continued biennially until the 1998 wave, at which point they were discontinued. (Note that we can recoup the working arrangements between these three waves from data contained in the respondents' work histories.) Using this information from the NLSY79, we extracted two datasets. The first uses information from the 1994, 1996 and 1998

surveys, ${ }^{4}$ including their retrospective content, to construct the pathways and durations of jobs held by respondents from 1992 onwards. The second sample uses the 1993 to 1998 waves of the NLSY79 for the analysis of wage development. ${ }^{5}$

We can identify two principal forms of atypical work in the NLSY79: 'temporary workers' and contractors/consultants. The former category comprises the separate categories of temporary agency workers and direct hire temporaries that we amalgamate on sample size grounds. ${ }^{6}$ Information on contractors and consultants is not separated out in the survey and is therefore a composite grouping to begin with. Another potential group of atypical workers, termed 'other work types,' can be identified in the survey. Since members of this group are disproportionately self-employed individuals, the decision was taken to exclude them. (We note parenthetically that a wider array of atypical jobs is available in the other main data set available to U.S. researchers in this area: the Contingent and Alternative Employment Arrangement Supplement (CAEAS) to the Current Population Survey. Unfortunately use of this material is precluded because we can at best identify worker histories for eighteen months.)

Using the data for our first sample identified above, we are able to trace the pathways used by workers engaged in temporary work over interval, 1992-98. Using the 
three main surveys and their retrospective components, we can identify the sequence of jobs and the associated work arrangements held by workers over this not inconsiderable interval. This sequencing provides us with some guidance as to whether temporary employment serves as a potential stepping stone into regular employment and of the employee characteristics that underpin such transitions. For each job held by workers, we also identify its industrial and occupational affiliation, the size of the employment unit, and the status of the job as either part-time or full-time. We use the demographic and other characteristics (e.g. age, education, region, ethnicity, etc.) of the worker at the time of each NLSY interview (1994, 1996 and 1998) to estimate their potential impact on job transitions; while for those transitions that take place between waves we take the worker characteristics recorded in the earlier survey (i.e. for different jobs).

Our second sample allows us to estimate the medium-term implications of temporary and contract work employment on a worker's wages. Like Booth, Francesconi, and Frank, we are able to identify the total number of temporary and contracting jobs held by a worker over the sample period, 1993-98. But we also seek to improve upon this measure by recording the number of years spent in either type of atypical employment on the grounds that worker remuneration is more likely to be impacted by a prolonged period of time spent in an atypical job - and, in particular, temporary employment - rather than just the frequency of such jobs. The wage data pertain to the primary job held by a respondent at the time of each NLSY interview. Note further that we included those temporary or contracting jobs starting and ending between any two waves in our measure of the time spent in atypical work. For temporal consistency, the wages of such jobs were not used in our wage analysis.

For both samples, we include information on the total amount of general labour market experience accrued by a worker since 1975 as a measure of accumulated (general) human capital and examine its implications for wage development and job transitions. We also constructed proxies for a worker's ability using the Armed Forces Qualification Test results reported in the 1981 NLSY. Specifically, proxies for a worker's mathematical, verbal, practical and scientific ability were constructed by using the test results for these general areas and then collecting the residuals obtained from the regression of scores on a vector of age and education dummies. 
Descriptive information on the remuneration and characteristics of our atypical workers is provided in Table 1. Slightly less than 13,500 jobs were recorded by the NLSY79 respondents over the period 1993-1998. From panel (a) of the table it can be seen that a little over 6 percent of all jobs held were temporary, whereas contracting or consulting positions were less than 2 percent of the total. The frequency of these two atypical work arrangements is slightly lower in our sample than for the U.S. workforce as a whole because of the older cohort of workers contained in the NLSY79 sample (see Cohany, 1998).

(Table 1 near here)

Panel (b) of Table 1 presents information on the inflation-adjusted average hourly wages of the three groups, while panel (c) provides $t$-tests of the respective wage differences. Temporary workers appear to fare poorly relative to those employed in either regular work or contracting/consulting. The $\$ 4.80$ differential reported for the whole sample represents a 45 percent wage disparity between temporary and regular work, and captures the much greater earnings penalty applying in the case of men than women. All wage differences between temporary and regular workers (and contracting/consulting workers) are statistically significant. When we compare contracting/consulting workers with regular workers, however, the broad earnings picture is reversed, although only in the case of females is the now favourable earnings gap (of almost \$4) statistically significant.

(Table 2 near here)

Table 2 presents information on job durations (panel (a)) and job pathways (panel (b)) over the 1992 to 1998 waves of NLSY79 data, with data from the 2000 wave being used to update the former information. Kaplan-Meier estimates of both completed and incomplete durations of the various work arrangements reveal that fully fifty percent of temporary jobs are completed within six months for both males and females. The median duration for contracting/consulting work at 1.83 years (1.7 years for males and 1.9 years for females) was more than twice that of temporary employment. Open-ended jobs had a median duration of just under three years for both males and females. Only four (two) percent of male (female) temporary jobs lasted more than five years as compared with almost 40 percent in the case of regular jobs. 
As for the pathways, slightly more than one-half of temporary and contracting/consulting workers remained in the same work arrangement over the sample period. Unsurprisingly, of those who transitioned out of either atypical work arrangement, regular employment rather than another form of atypical work was the preferred path: 48 percent of the agency temps and 45 percent of contractors/consultants subsequently entered open-ended employment. The transition rates out of regular work show that this is a highly stable work arrangement: more that 96 percent of all those initially in regular employment either took another regular job or remained in the same job across all seven years of the sample period.

With these preliminaries behind us, what is the cet. par. evidence on transitions and wage development?

\section{Findings}

We have seen that the majority of atypical workers transition into permanent employment. But what type of workers are they? To address this issue, we specify a discrete time proportional hazard model in the manner of Booth, Francesconi, and Frank, linking transitions into open-ended employment to a number of individual attributes, including AFQT scores, and job specific characteristics. The model is estimated for temporary agency workers alone because small sample size prohibited estimation in the case of contractors/consultants. Although the covariates are not identical as between our two studies, the results make sense in general and are relatively consistent with the findings of the British study.

(Table 3 near here)

Thus, from Table 3, we see age - here a continuous rather than a categorical variable - is strongly negatively associated with transitions into open-ended employment and for both genders (whereas this is the case for males alone in Britain). The coefficient estimate for schooling - again a continuous rather than a categorical variable here - is positive throughout. That said, it is not statistically significant for females. Interestingly, black male temporary workers have a heightened probability of exiting into regular employment than their white counterparts whereas the opposite is true for Hispanics of both genders, even if this latter result is only marginally significant for females. The 
incorporation of AFQT scores is somewhat disappointing. Although higher verbal ability improves the chances of exiting from temporary work into regular employment for females, this is not true for males for whom the coefficient estimate is negative albeit statistically insignificant. For its part, practical ability appears to detract from transitioning into regular employment for females. Unlike the British case, part-time status has no adverse effect on transition rates. Nor for that matter is employer size related to transitions into regular employment, which might suggest that it is not only large employers that use temporary employment as a screen. The contribution of industrial affiliation is statistically insignificant throughout with the one exception of the personal services sector. Males in this sector are less likely to transition into regular employment. Interestingly, Booth, Francesconi, and Frank obtain the same result for the 'protection and personal services' occupation in respect of casual (if not fixed-term) work. Finally, none of our occupational coefficients proved statistically significant.

To what extent do the large wage gaps between regular, open-ended employment and temporary work observed for males and females, but especially the former, reflect differential human capital endowments and the like. In Table 4 we report simple OLS regressions to measure the effects of such factors on log wages. Our regressors include those used earlier in modeling (temporary) worker transitions into regular employment. They are augmented in the manner of Booth Francsconi, and Frank, to include labour market experience. The authors measure experience as over the survey period; we measure it as time spent in employment since 1976 , as this more accurately captures a workers true workforce experience, and, as a result, is a better reflection of how experience impacts wages. Following Booth et al., we also include linear and quadratic number of previous jobs held (i.e. the number of temporary jobs and the number of contracting/consulting jobs) as well as interactions between each and lifetime experience to determine whether the returns to experience differ by contract type.

\section{(Table 4 near here)}

Table 4 presents summary results of our wage regressions. ${ }^{7}$ The basic result is that, after controlling for human capital, observed ability, and demographic, industrial and occupational differences, atypical work appears to have few adverse implications for female earnings over the 1993-98 interval, while unfavourably impacting males earnings. 
Focusing on the separate findings for males and females, and beginning with the results in column (3) of the table, we see that each temporary job held by males serves to reduce wages, by very roughly twenty-one percent, when compared to those males who never held a temporary job. The coefficient estimate for the quadratic term suggests that this gap falls with the number of jobs taken over the five-year interval. Observe that the estimated cet. par. differential is around one-half that of the crude wage gap earlier reported in Table 1, suggesting that a good portion of the wage disadvantage for males in temporary employment can be attributable to other observed characteristics. There are seemingly modest differences between the wages of males employed in contracting/consulting work and those of their counterparts in regular employment. Finally, there is the general result that additional years of general labour market experience have positive implications for wages development: each year of additional lifetime experience increases earnings by approximately five percent.

The results presented in the next column of the table look beyond the latter finding in providing estimates of any differential effect of atypical work on experience capital. Given the transitory nature of temporary jobs, it might not be unexpected to see a lesser return vis-à-vis open-ended employment. Although the coefficient estimates for the interaction terms are statistically insignificant, for male workers with one year of lifetime experience the implied penalty to one temporary job over the first six years of the career is approximately $25.1 \%$ falling to $16.4 \%$ with ten years experience. For male contracting/ consulting workers the corresponding values are a premium of $27.5 \%$ falling to a penalty of $4.1 \%$. In the case of females a premium is implied for one atypical job over the first six years of a career, although as can be seen from column (5) of the table this declines for temporary and contracting/consulting workers with ten years of experience, and is actually reversed (i.e. becomes a penalty) in the case of temporaries.

In focusing on the number of atypical jobs held by a worker to derive the above results, we are not accounting directly for the actual time spent in such work arrangements. As an extreme example, consider two workers one of whom takes a temporary job as a (certain) stepping stone into regular employment while the other spends the entire six-year period in the same temporary job. Both workers will record only one temporary job, but it seems unlikely that this would have the same effect on each 
worker's earnings. To investigate this issue, we further exploited the work diaries maintained by the NLSY79 respondents to derive a measure of the number of years spent in each type of atypical employment. We then substituted this measure for the number of jobs argument(s). Summary findings of our re-estimations are contained in Table 5.

(Table 5 near here)

As was the case in Table 4, spending time in temporary employment is more detrimental for males. The results obtained in the column (3) of Table 5 indicate that each year spent by a male in temporary work reduces his earnings by about $15 \%$, although the coefficient estimate for the quadratic term again suggests that there is some mitigation of this wage penalty over the employment interval. For females, the results given in column (5) of the table indicate that temporary employment plays even less of a role than before in the determination of their earnings once other observed differences are taken into account. Focusing on the results in columns (4) and (6), however, we can see that the cost of working as a temporary worker for one year results in a continuing penalty for both genders. For males, the penalty is $23.8 \%$ after a year falling modestly to $17.1 \%$ after ten years. But for females the penalty is just 3.25\% after one year and $0.95 \%$ after ten years. There is no such continuing penalty in the case of one year's employment in contracting/consulting job. For males there is actually a premium (of $24.7 \%$ after one year falling to $4.6 \%$ after ten years). For females there is even some suggestion of a penalty being transformed into a modest premium (from $-14.4 \%$ after one year to $3.5 \%$ after ten years).

(Figures 1 and 2 near here)

The effects of different contract types on wages can be explored diagrammatically by describing wage paths for a number of career choices. Again using the coefficient estimates in Tables 4 and 5, we construct four such synthetic profiles for males and females. Profile 1 describes the case where the worker is employed in a permanent job throughput the sample period. Profile 2 (3) depicts a situation in which the worker holds a temporary (contracting/consulting) job in the first period, followed by employment in a permanent job therereafter. Finally, profile 4 is the case where the worker holds three temporary jobs before transitioning into permanent employment. These wage trajectories are reproduced in Figures 1 and 2, respectively. 
Beginning with the specification based on the number of atypical jobs, it is apparent from Figure 1 that male contracting and consulting workers are a cut above the rest and conversely for their fellows in temporary jobs. That is, workers who take either one or three temporary jobs before transitioning into regular open-ended employment earn less and continue to earn less than their counterparts in continuous regular employment, the gap between them narrowing only very slowly over time. It is as if the number of temporary jobs directly proxies unobserved differences in ability. As far as male consulting/contracting jobs are concerned, no earnings benefit accrues to switching out of this type of atypical work into regular employment since the earnings gap favoring former contracting/consulting workers narrows through time although it certainly persists over the time frame considered in the figure.

The picture for women is somewhat different. Most obviously the structure is much less dispersed and the gaps between profiles less pronounced. Points of contact with the male trajectories are, first, that former contracting/consulting workers continue to earn the most, although the gap between them and regular workers narrows, and, second, that those with three temporary jobs before they transition into regular employment continue to earn distinctly less than regular workers and actually deteriorate relatively. The main difference, then, is that those with one temporary job who transition into regular employment seemingly earn more than ever-regular workers to begin with but are subsequently overtaken by them. That said, the earnings gaps in question are very modest. With the possible exception of profile 4 types, there is little to suggest in the female case that number of temporary jobs might proxy unobserved heterogeneity.

Figure 2 replaces the number of jobs measure with time spent in atypical jobs. The earnings profiles shown for males fairly closely follow those reported earlier in Figure 1. That is to say there is no indication that switching out of temporary work into regular work is associated with catch up, while the earnings advantage of former consulting/contracting workers is now subject to less erosion. As far as females are concerned, however, there is much stronger evidence of catch up in the wake of transitions from one or three temporary jobs into regular employment. And for this specification, those transitioning from contracting/consulting work display the sharpest earnings progression of all, albeit from the lowest starting point. 


\section{Conclusions}

Reflecting data considerations, there has been rather less investigation of the nature and consequences of atypical work in the United States than in Europe. Of late, this imbalance has if anything grown. Partly for this reason, the extant U.S. evidence on the implications of atypical work for employment continuity and wages is also more polarized, with some observers continuing to characterize atypical work as providing dead end jobs with poor wages and prospects and others seeing them more as stepping stones to permanent or at least regular employment. The caveat is that some atypical jobs in the United States have always been regarded as paying well, even offering a premium over regular, open-ended employment.

In this note, we have sought to offer a fresh view of the U.S. evidence by examining job transitions and wage development for two atypical jobs at either end of the wage continuum: temporary workers, comprising agency and direct hire temps, and consulting/contracting workers. In this endeavour we have drawn directly on Booth, Francesconi, and Frank's (2002) important study of workers on fixed-term contracts and those in casual and seasonal jobs, published as part of an EJ symposium on temporary work in Europe. Although we are unable to investigate the job satisfaction enjoyed by temporary workers or examine their training opportunities as do these authors, we can broadly replicate their treatment of the effects of temporary work on career prospects subject to the limitations of the U.S. data.

And we report a real measure of support for Booth, Francsconi, and Frank with respect to our (different) category of temporary workers, while at the same time confirming past research on the more privileged position of contracting/consulting workers. That is to say, on the negative side we find that male temps suffer a material cet. par. wage disadvantage that persists with only very slight sign of narrowing after the transition into regular work More positively, the situation confronting female temporary workers is much brighter, also in line with Booth, Francesconi, and Frank, at least for our

preferred measure of time spent in atypical work. The difference in our case is that there is less evidence of a wage penalty to begin with. 
At a descriptive level, temporary jobs are indeed stepping stones to regular employment. But unobserved differences in worker quality seemingly lie behind the finding that males who enter regular employment after one or more spells of temporary work close the gap at a glacial rate. For females on the other hand any earnings gap associated with taking temporary jobs before entering regular employment is modest to begin with and narrows over time. There is only the slenderest of evidence pointing to unobserved quality differences between females in atypical employment and their counterparts in regular employment. 


\section{Footnotes}

1. Atypical worker directives dealing with part-timers, fixed-term contract workers, and agency temps were first mooted in the early 1980s but draft legislation covering the first two groups was not enacted into law until in the late 1990s (see Official Journal, 1998, 1999, respectively). Legislation on agency workers has proved altogether more controversial given the diversity of law and custom practice within the EU. Thus, for example, the present legislation was first proposed by the Commission in 2002. Final passage of the draft legislation some six years later hinged on a mix of external and internal concessions. The former included British opt-outs on yet more controversial legislation in the form of the ultimately abortive working hours' directive. Among the internal concessions, apart from the derogation noted in the text, was the exemption from equal treatment in respect of pay where agency temps having a permanent employment contract with their agency continued to be paid between assignments.

2. By the same token, member states are to review existing restrictions or prohibitions of the use of temporary agency workers - presumably including limits on the sectors or special situations in which temporary agency workers can be used or on the maximum duration of assignments - in order to verify that they are justified on grounds of health and safety 'or the need to ensure that the labour market functions properly and abuses are prevented.' Note that these provisions, however, do not cover national requirements on the registration, licensing, certification, financial guarantees or monitoring of temporary work agencies.

3. But for a review of the U.S. atypical worker wage literature, see Addison and Surfield (2007).

4. In addition, data from the 2000 wave is used to update the durations of jobs held by respondents in 1998; see Table 2.

5. For our second sample, we do not go back further than 1993 given the progressive loss of data on both pay and work type prior to this wave of the NLSY79. We can go a little further back in the case of out first sample because we are not concerned with wage data but only jobs.

6. See Addison and Surfield (2009) on the efficacy of this aggregation. 
7. A number of regressors in our wage equation are likely to be correlated with unobserved individual and job-specific characteristics. Unfortunately, given insufficient variation in the number of jobs held by respondents, we were unable to fully instrument for potentially endogenous variables in the manner of Booth, Francesconi, and Frank (see their IV/GLS estimates in Table 6). We understand that this is a limitation of this part of the analysis, but feel that the estimates provided are still highly informative. 


\section{References}

Addison, John T. and Christopher J. Surfield. 2009. "Atypical Work and Employment Continuity." Industrial Relations 48 (October): 655-683.

Addison, John T. and Christopher J. Surfield. 2007. "Atypical Work and Pay." Southern Economic Journal 73 (April): 1038-1065.

Booth, Alison L., Juan J. Dolado, and Jeff Frank. 2002. "Symposium on Temporary Work Introduction.” Economic Journal 112 (June): F181-F188.

Booth, Alison L., Marco Francesconi, and Jeff Frank. 2002. Economic Journal 112 (June): F189-F213.

Cohany, Sharon R. 1998. "Workers in Alternative Work Arrangements: A Second Look." Monthly Labor Review 121 (November): 3-21.

Official Journal. 1998. "Council Directive 97/81/EC of 15 December 1997 concerning the Framework Agreement on part-time work concluded by UNICE, CEEP and the ETUC." Official Journal of the European Communities OJ L 14 of 20.1.1998, pp. 9-14.

Official Journal. 1999. "Council Directive 97/70/EC of 28 June 1999 concerning the framework agreement on fixed-term work concluded by ETUC, UNICE and CEEP." Official Journal of the European Communities OJ L 175 of 10.7.1999, pp. 43-48.

Official Journal. 2008. Directive 2008/104/EC of the European Parliament and of the Council of 19 November 2008 on temporary work. Official Journal of the European Communities L327 of 5.12.2008, pp. 9-14.

Kvasnika, Michael. 2008. "Does Temporary Help Work Provide a Stepping Stone to Regular Employment?” NBER Working Paper No. 13843. Cambridge, MA: National Bureau of Economic Research.

Freier, Ronny and Viktor Steiner. "Marginal Employment': Stepping Stone or Dead End? Evaluating the German Experience." Zeitschrift für ArbeitsmarktForschung (2/3): 223243.

García-Pérez, J. Ignacio and Fernando Muñoz-Bullón. 2003. “The Nineties in Spain: Too Much Flexibility in the Youth Labour Market." Working Paper No. 03-03 (02), Business Economics Series. Madrid: Universidad Carlos IIII de Madrid

Ichino, Andrea, Fabrizzia Mealli, and Tommaso Nannicini. 2004. "Temporary Work Agencies in Italy: A Springboard Towards Permanent Employment? Unpublished Paper, European University Institute. 
Ichino, Andrea, Fabrizzia Mealli, and Tommaso Nannicini. 2008." From Temporary Help Jobs to Permanent Employment: What Can We Learn from Matching Estimators and Their Sensitivity? Journal of Applied Econometrics 23 (3): 305-327.

Portugal, Pedro and José Varajão. 2009. "Why Do Firms Use Fixed-Term Contracts?" IZA Discussion Paper No. 4380. Bonn: Institute for the Study of Labor (Forthcoming in Journal of Labor Economics).

Zijl, Marloes, Gerard J. van den Berg, and Arjan Heyma. 2004. "Stepping Stones for the Unemployed: The Effect of Temporary Jobs on the Duration until Regular Work." IZA Discussion Paper No. 1241. Bonn: Institute for the Study of Labor (Forthcoming in Journal of Population Economics). 
Table 1

Distribution of Temporary and Contracting/Consulting Work and Mean Hourly Wages by Type of Contract and Gender (wages in constant 1982-84 dollars)

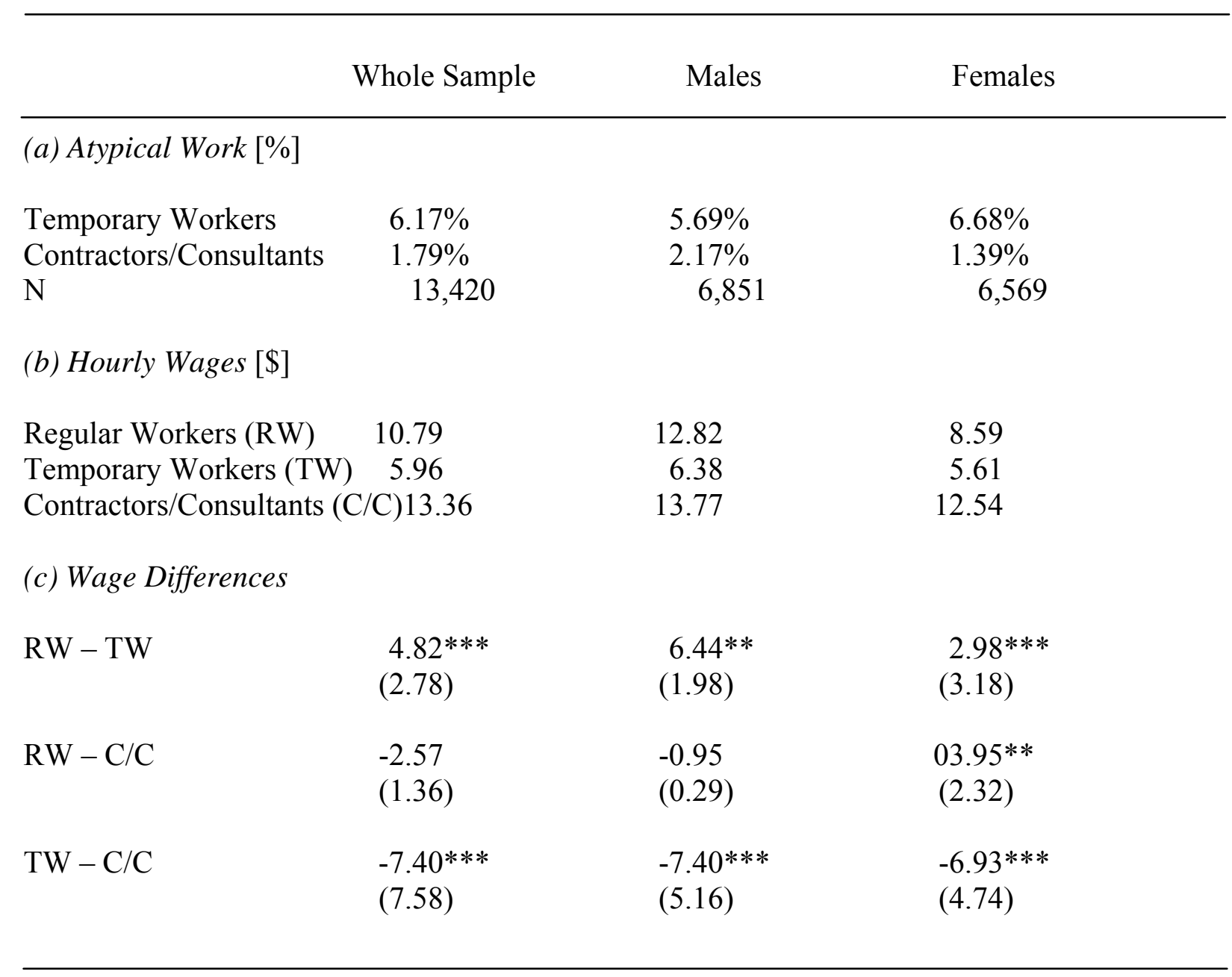

Source: NLSY79, 1993-98.

Notes: Wages are expressed in constant 1982-84 dollars. Absolute values of the $t$-test of the wage differences are in parentheses; ***, ** indicating that the difference is statistically significant at the 0.01 and 0.05 levels, respectively. 
Table 2

Labor Market States, Employment Duration and Transition Rates

(a) Employment Duration, by Work Arrangement

Regular Workers Temporary Workers Contractors/Consultants

Average, in years

(standard deviation)

5.04

$(5.43)$

1.18

2.60

(1.68)

$(2.51)$

Median, in years

2.96

0.60

1.83

(b) Transition Rates, by Work Arrangement

\begin{tabular}{lrrr} 
& \multicolumn{3}{c}{ Next or Ending Work Arrangement } \\
\cline { 2 - 4 } Initial Arrangement & Regular Work & Temporary Work & Contracting/Consulting \\
Regular Work & $11,918(96.49 \%)$ & $340(2.75 \%)$ & $94(0.76 \%)$ \\
Temporary Work & $399(48.19 \%)$ & $421(50.85 \%)$ & $8(0.87 \%)$ \\
Contracting/Consulting & $108(45.00 \%)$ & $8(3.33 \%)$ & $124(51.67 \%)$ \\
$\mathrm{N}$ & $12,425(92.59 \%)$ & $769(5.73 \%)$ & $226(1.68 \%)$ \\
\hline
\end{tabular}

Source: NLSY79, 1992-98. 
Table 3

Exit from Temporary Agency Work to Regular Work

(Estimates from a proportional hazard model, non-parametric baseline hazard specification)

Transition from Temporary to Regular Employment

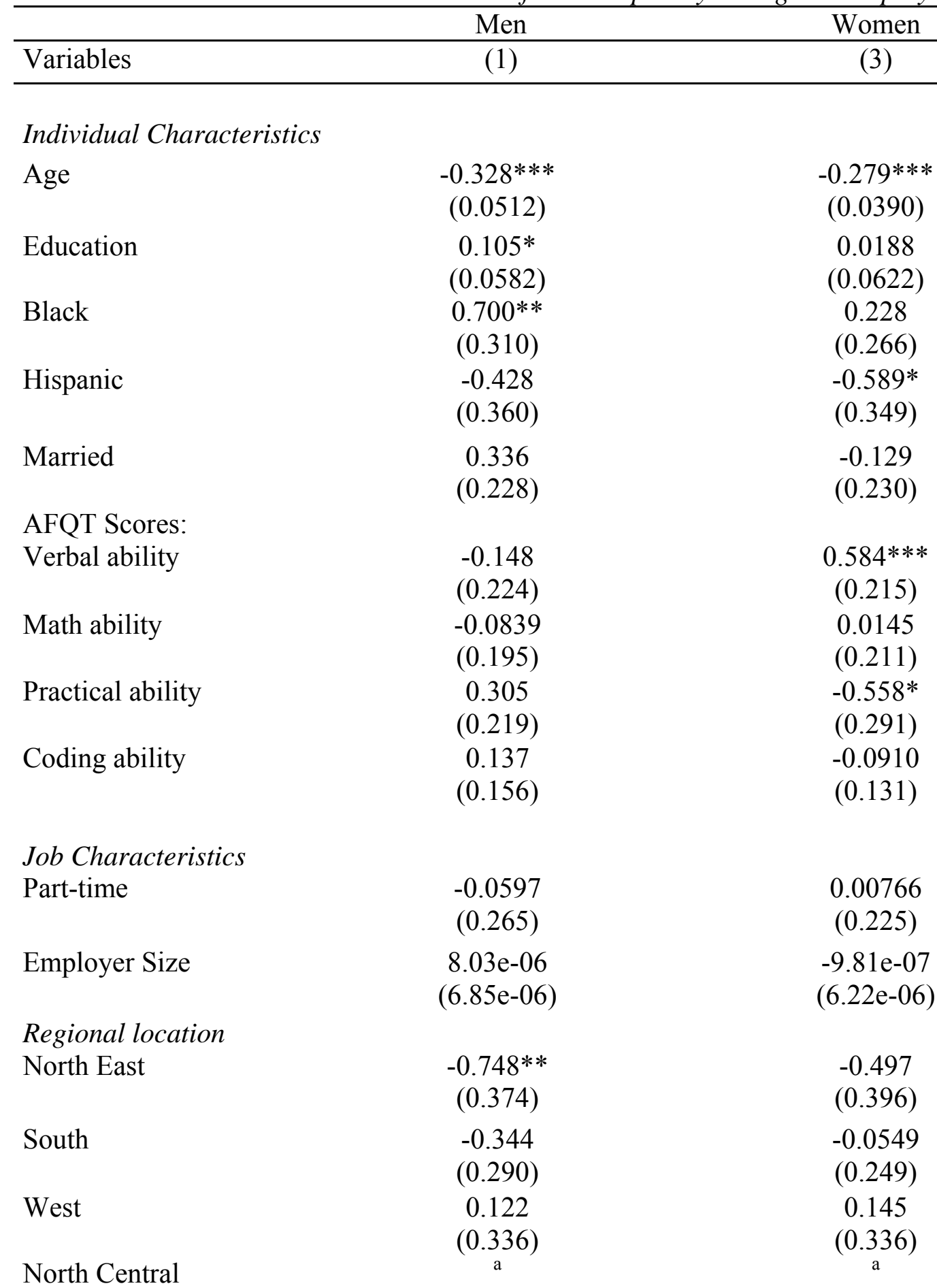




$\begin{array}{lcc}\text { Industrial Sector } & & \\ \text { Agriculture } & -1.090 & 0.185 \\ & (1.444) & (0.691) \\ \text { Mining } & -1.069 & 0.587 \\ & (1.345) & (0.961) \\ \text { Manufacturing } & -1.237 & -0.189 \\ & (1.341) & (0.619) \\ \text { Transport./ } & -1.170 & 0.634 \\ \text { Comm. } & (1.454) & (0.656) \\ \text { Trade } & -1.298 & 0.267 \\ & (1.391) & (0.556) \\ \text { Business Service } & -0.898 & 0.407 \\ & (1.309) & (0.594) \\ \text { Professional } & -1.140 & 0.0981 \\ \text { Service } & (1.372) & (0.573) \\ \text { Personal Service } & -2.602 * & -0.766 \\ & (1.494) & (0.641) \\ \text { Public } & -1.327 & 0.0964 \\ \text { Administration } & (1.372) & (0.633) \\ \text { FIRE } & \mathrm{a} & \mathrm{a}\end{array}$

$\begin{array}{lcc}\text { Employment Capacity } & & \\ \text { Managerial } & -0.0147 & -0.477 \\ & (0.680) & (0.537) \\ \text { Clerical } & 0.580 & -0.00606 \\ & (0.911) & (0.432) \\ \text { Service } & 0.480 & 0.626 \\ & (0.709) & (0.459) \\ \text { Operator/ } & 0.341 & 0.0212 \\ \text { Laborer } & (0.701) & (0.464) \\ \text { Skilled laborer } & 0.0526 & 0.176 \\ & (0.746) & (0.564) \\ \text { Technical/Sales } & \mathrm{a} & \mathrm{a}\end{array}$

\begin{tabular}{lcc}
\hline Log-likelihood & -415.4 & -485.8 \\
$\chi^{2}$ & 120.74 & 92.38 \\
& {$[0.0000]$} & {$[0.0000]$} \\
$\mathrm{N}$ & 192 & 236 \\
\hline
\end{tabular}

Notes: Robust standard errors are given in parentheses. Standard errors have been clustered by the individual. The model $\chi^{2}$ statistic has 28 degrees of freedom and its p-value is shown in brackets. Ability scores were obtained by taking the scores reported by the respondents in the 1981 AFQT and regressed on a vector of age and education dummies. The residuals are represented in these variables. The test scores were combined into one of four types of ability: verbal, mathematical, practical, and coding ability. ${ }^{\text {a }}$ indicates excluded group. Estimation was also performed with gamma-distributed latent random effects in order to capture unobserved heterogeneity between individuals. Since the gamma variance parameter converged to zero, results of this procedure are not reported here, but are available upon request. $* * *, * * *$ denote statistical significance at the $0.01,0.05$, and 0.10 levels, respectively. 
Table 4

Impact of Temporary and Contract Work Spells on Log Wages, Summary Results

\begin{tabular}{|c|c|c|c|c|c|c|}
\hline \multirow[b]{2}{*}{ Variables } & \multicolumn{2}{|c|}{ Whole Sample } & \multicolumn{2}{|c|}{ Men } & \multicolumn{2}{|c|}{ Women } \\
\hline & $(1)$ & $(2)$ & (3) & (4) & $(5)$ & $(6)$ \\
\hline No. Temporary Jobs (NTJ) & $\begin{array}{c}-0.139 * * * \\
(0.0318)\end{array}$ & $\begin{array}{l}-0.0878 \\
(0.0788)\end{array}$ & $\begin{array}{c}-0.230 * * * \\
(0.0485)\end{array}$ & $\begin{array}{c}-0.313 * \\
(0.183)\end{array}$ & $\begin{array}{l}-0.0654 * \\
(0.0372)\end{array}$ & $\begin{array}{c}0.0432 \\
(0.0623)\end{array}$ \\
\hline No. Temporary Jobs ${ }^{2}$ & $\begin{array}{c}0.0198 \\
(0.0145)\end{array}$ & $\begin{array}{c}0.0169 \\
(0.0150)\end{array}$ & $\begin{array}{c}0.0486 * * \\
(0.0220)\end{array}$ & $\begin{array}{c}0.0438 * * \\
(0.0221)\end{array}$ & $\begin{array}{l}-0.00258 \\
(0.0140)\end{array}$ & $\begin{array}{l}-0.00522 \\
(0.0139)\end{array}$ \\
\hline NTJ*lifetime experience & & $\begin{array}{c}-0.00494 \\
(0.0118)\end{array}$ & & $\begin{array}{c}0.0193 \\
(0.0280)\end{array}$ & & $\begin{array}{l}-0.0191 * \\
(0.0105)\end{array}$ \\
\hline $\mathrm{NTJ}^{*}$ lifetime experience ${ }^{2}$ & & $\begin{array}{c}8.00 \mathrm{e}-05 \\
(0.000454)\end{array}$ & & $\begin{array}{l}-0.000884 \\
(0.000989)\end{array}$ & & $\begin{array}{c}0.000747 \\
(0.000461)\end{array}$ \\
\hline No. Contract/Consult. Jobs (NCJ) & $\begin{array}{l}-0.0747 \\
(0.0893)\end{array}$ & $\begin{array}{c}0.125 \\
(0.181)\end{array}$ & $\begin{array}{l}-0.139 \\
(0.109)\end{array}$ & $\begin{array}{c}0.223 \\
(0.280)\end{array}$ & $\begin{array}{c}0.134 \\
(0.164)\end{array}$ & $\begin{array}{c}0.134 \\
(0.234)\end{array}$ \\
\hline No. Contract/ Consult. Jobs ${ }^{2}$ & $\begin{array}{c}0.0837 \\
(0.0528)\end{array}$ & $\begin{array}{l}0.0904 * \\
(0.0527)\end{array}$ & $\begin{array}{c}0.102 * \\
(0.0579)\end{array}$ & $\begin{array}{c}0.108^{*} \\
(0.0590)\end{array}$ & $\begin{array}{l}-0.0351 \\
(0.109)\end{array}$ & $\begin{array}{c}-0.00712 \\
(0.114)\end{array}$ \\
\hline NCJ*lifetime experience & & $\begin{array}{l}-0.0412 \\
(0.0370)\end{array}$ & & $\begin{array}{l}-0.0585 \\
(0.0542)\end{array}$ & & $\begin{array}{l}-0.0262 \\
(0.0358)\end{array}$ \\
\hline $\mathrm{NCJ}^{*}$ lifetime experience ${ }^{2}$ & & $\begin{array}{c}0.00173 \\
(0.00155)\end{array}$ & & $\begin{array}{c}0.00213 \\
(0.00224)\end{array}$ & & $\begin{array}{c}0.00161 \\
(0.00130)\end{array}$ \\
\hline Current lifetime experience & $\begin{array}{c}0.0526^{* * *} \\
(0.00412)\end{array}$ & $\begin{array}{c}0.0545 * * * \\
(0.00442)\end{array}$ & $\begin{array}{c}0.0526 * * * \\
(0.00665)\end{array}$ & $\begin{array}{c}0.0533 * * * \\
(0.00720)\end{array}$ & $\begin{array}{l}0.0465 * * * \\
(0.00514)\end{array}$ & $\begin{array}{c}0.0489 * * * \\
(0.00550)\end{array}$ \\
\hline Current lifetime experience ${ }^{2}$ & $\begin{array}{c}-0.00055 * * * \\
(0.00015)\end{array}$ & $\begin{array}{c}-0.00062 * * * \\
(0.00016)\end{array}$ & $\begin{array}{c}-0.00072 * * * \\
(0.00023)\end{array}$ & $\begin{array}{c}-0.00073 * * * \\
(0.00024)\end{array}$ & $\begin{array}{l}-0.00037 * \\
(0.00019)\end{array}$ & $\begin{array}{c}-0.00047 * * \\
(0.00020)\end{array}$ \\
\hline Constant & $\begin{array}{c}0.865^{* * *} \\
(0.0862)\end{array}$ & $\begin{array}{c}0.856^{* * *} \\
(0.0864)\end{array}$ & $\begin{array}{c}0.806 * * * \\
(0.126)\end{array}$ & $\begin{array}{c}0.805^{* * *} \\
(0.126)\end{array}$ & $\begin{array}{c}0.792 * * * \\
(0.116)\end{array}$ & $\begin{array}{c}0.776^{* * *} \\
(0.116)\end{array}$ \\
\hline $\mathrm{R}^{2}$ & 0.378 & 0.378 & 0.344 & 0.344 & 0.417 & 0.417 \\
\hline Observations & \multicolumn{2}{|c|}{14138} & \multicolumn{2}{|c|}{7826} & \multicolumn{2}{|c|}{6312} \\
\hline Individuals & \multicolumn{2}{|c|}{4731} & \multicolumn{2}{|c|}{2516} & \multicolumn{2}{|c|}{2215} \\
\hline
\end{tabular}

Notes: Robust standard errors are given in parentheses. Each specification also includes dummy variables for region, race, ethnicity, marital status, part-time status, occupation, industry, firm size, and proxies for ability/aptitude derived from AFQT scores, as well as a measure of worker age. All robust standard errors are listed in parentheses. $* * *, * * *$ denote statistical significance at the $0.01,0.05$, and 0.10 levels, respectively. 
Table 5

Impact of Time in Temporary and Contract Work on Log Wages, Summary Results

\begin{tabular}{|c|c|c|c|c|c|c|}
\hline \multirow[b]{2}{*}{ Variables } & \multicolumn{2}{|c|}{ Whole Sample } & \multicolumn{2}{|c|}{ Men } & \multicolumn{2}{|c|}{ Women } \\
\hline & (1) & $(2)$ & (3) & $(4)$ & $(5)$ & (6) \\
\hline No. Years in Temporary Jobs (YTJ) & $\begin{array}{c}-0.0968 * * * \\
(0.0218)\end{array}$ & $\begin{array}{l}-0.0805 \\
(0.0737)\end{array}$ & $\begin{array}{c}-0.167 * * * \\
(0.0320)\end{array}$ & $\begin{array}{c}-0.262 * * \\
(0.122)\end{array}$ & $\begin{array}{l}-0.0111 \\
(0.0516)\end{array}$ & $\begin{array}{c}-0.0329 \\
(0.109)\end{array}$ \\
\hline No. Years in Temporary Jobs ${ }^{2}$ & $\begin{array}{c}0.00826 * * * \\
(0.00249)\end{array}$ & $\begin{array}{c}0.00839 * * * \\
(0.00269)\end{array}$ & $\begin{array}{l}0.0150 * * * \\
(0.00324)\end{array}$ & $\begin{array}{c}0.0144 * * * \\
(0.00362)\end{array}$ & $\begin{array}{l}-0.00575 \\
(0.0191)\end{array}$ & $\begin{array}{l}-0.00495 \\
(0.0187)\end{array}$ \\
\hline YTJ *lifetime experience & & $\begin{array}{l}-0.00247 \\
(0.0108)\end{array}$ & & $\begin{array}{l}0.00949 \\
(0.0176)\end{array}$ & & $\begin{array}{l}0.00560 \\
(0.0132)\end{array}$ \\
\hline YTJ $*$ lifetime experience ${ }^{2}$ & & $\begin{array}{c}8.42 \mathrm{e}-05 \\
(0.000363)\end{array}$ & & $\begin{array}{l}-0.000179 \\
(0.000595)\end{array}$ & & $\begin{array}{l}-0.000276 \\
(0.000417)\end{array}$ \\
\hline No. Years in Contract Jobs (YCJ) & $\begin{array}{c}0.0551 \\
(0.0339)\end{array}$ & $\begin{array}{r}-0.00233 \\
(0.0961)\end{array}$ & $\begin{array}{c}0.0279 \\
(0.0363)\end{array}$ & $\begin{array}{l}0.288 * \\
(0.156)\end{array}$ & $\begin{array}{c}0.0526 \\
(0.0714)\end{array}$ & $\begin{array}{l}-0.179 \\
(0.144)\end{array}$ \\
\hline No. Years in Contract Jobs ${ }^{2}$ & $\begin{array}{c}-0.0111 \\
(0.00893)\end{array}$ & $\begin{array}{c}-0.0114 \\
(0.00903)\end{array}$ & $\begin{array}{l}-0.0115^{*} \\
(0.00664)\end{array}$ & $\begin{array}{l}-0.00963 \\
(0.00695)\end{array}$ & $\begin{array}{l}0.00445 \\
(0.0220)\end{array}$ & $\begin{array}{l}0.00696 \\
(0.0185)\end{array}$ \\
\hline YCJ $*$ lifetime experience ${ }^{2}$ & & $\begin{array}{c}-0.000214 \\
(0.000421)\end{array}$ & & $\begin{array}{c}0.000998 * \\
(0.000604)\end{array}$ & & $\begin{array}{l}-0.000775 \\
(0.000753)\end{array}$ \\
\hline Current lifetime experience & $\begin{array}{c}0.0529 * * * \\
(0.00401)\end{array}$ & $\begin{array}{c}0.0526 * * * \\
(0.00408)\end{array}$ & $\begin{array}{c}0.0541 * * * \\
(0.00652)\end{array}$ & $\begin{array}{c}0.0550 * * * \\
(0.00663)\end{array}$ & $\begin{array}{c}0.0482 * * * \\
(0.00508)\end{array}$ & $\begin{array}{c}0.0458 * * * \\
(0.00516)\end{array}$ \\
\hline Current lifetime experience ${ }^{2}$ & $\begin{array}{c}-0.00056^{* * *} \\
(0.00014)\end{array}$ & $\begin{array}{c}-0.00055^{* * *} * \\
(0.00014)\end{array}$ & $\begin{array}{c}-0.00072 * * * \\
(0.00022)\end{array}$ & $\begin{array}{c}-0.00076^{* * *} * \\
(0.00022)\end{array}$ & $\begin{array}{c}-0.00043 * * \\
(0.00019)\end{array}$ & $\begin{array}{l}-0.00035^{*} \\
(0.00019)\end{array}$ \\
\hline Constant & $\begin{array}{c}0.817 * * * \\
(0.0765)\end{array}$ & $\begin{array}{c}0.819 * * * \\
(0.0766)\end{array}$ & $\begin{array}{c}0.685 * * * \\
-0.167 * * *\end{array}$ & $\begin{array}{c}0.678 * * * \\
(0.113)\end{array}$ & $\begin{array}{c}0.834 * * * \\
(0.104)\end{array}$ & $\begin{array}{c}0.849 * * * \\
(0.104)\end{array}$ \\
\hline $\mathrm{R}^{2}$ & 0.383 & 0.383 & 0.351 & 0.351 & 0.416 & 0.416 \\
\hline Observations & \multicolumn{2}{|c|}{15949} & \multicolumn{2}{|c|}{8688} & \multicolumn{2}{|c|}{7258} \\
\hline Individuals & \multicolumn{2}{|c|}{4811} & \multicolumn{2}{|c|}{2553} & \multicolumn{2}{|c|}{2258} \\
\hline
\end{tabular}

Notes: Robust standard errors are given in parentheses. Each specification also includes dummy variables for region, race, marital status, part-time status, occupation, industry, firm size, and proxies for ability/aptitude derived from AFQT scores, as well as a measure of worker age. All robust standard errors are listed in parentheses. $* * *, * * *$ denote statistical significance at the $0.01,0.05$, and 0.10 levels, respectively. 


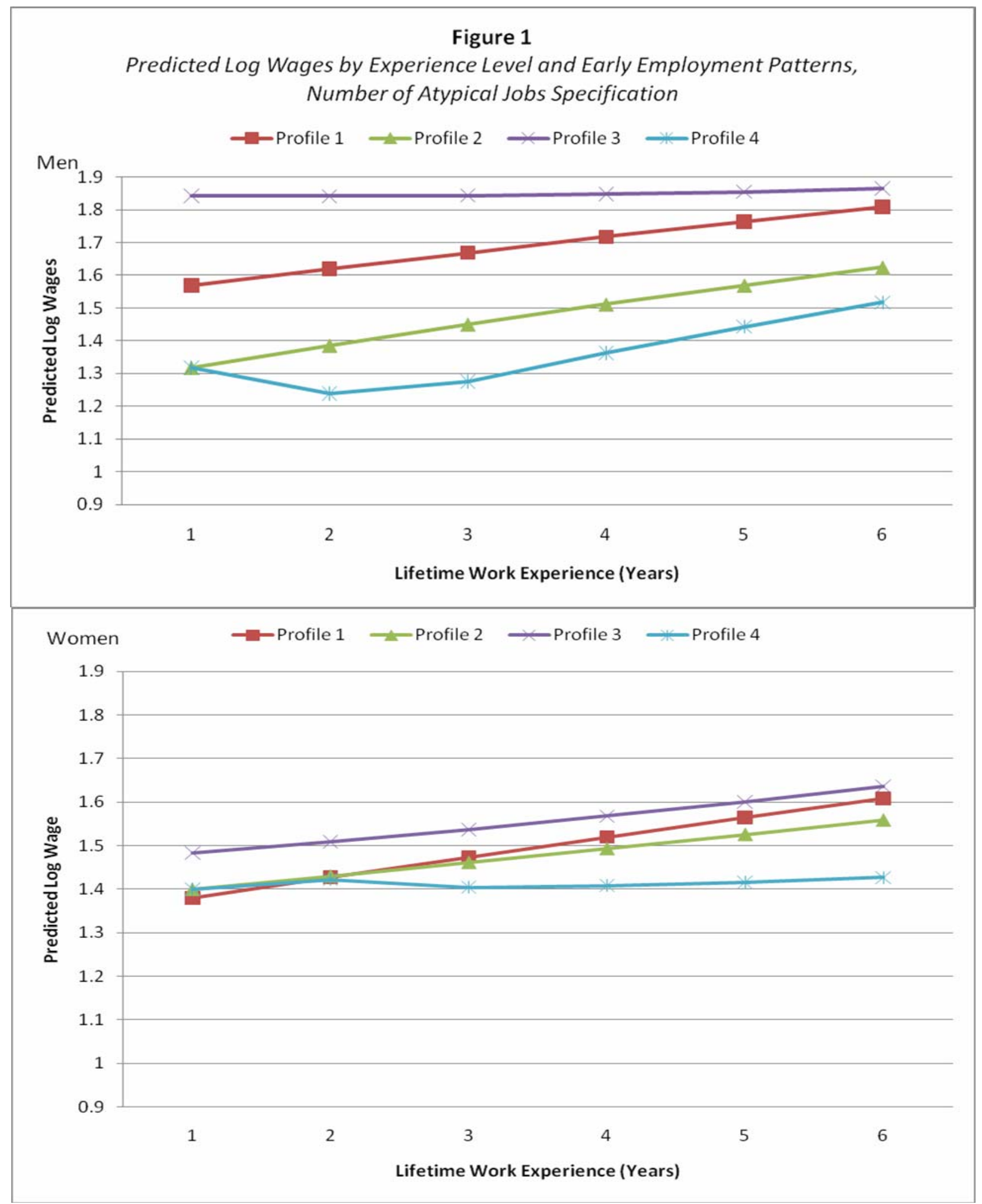

Notes: Predictions based on the estimates provided in Table 4. Pattern 1: Worker is always employed in a permanent job. Pattern 2: Worker holds one temporary job in first period and is employed in permanent employment thereafter. Pattern 3: Worker holds one contracting/consulting job and is employed in permanent employment thereafter. Pattern 4: Worker holds three temporary jobs and then is employed in permanent employment. 


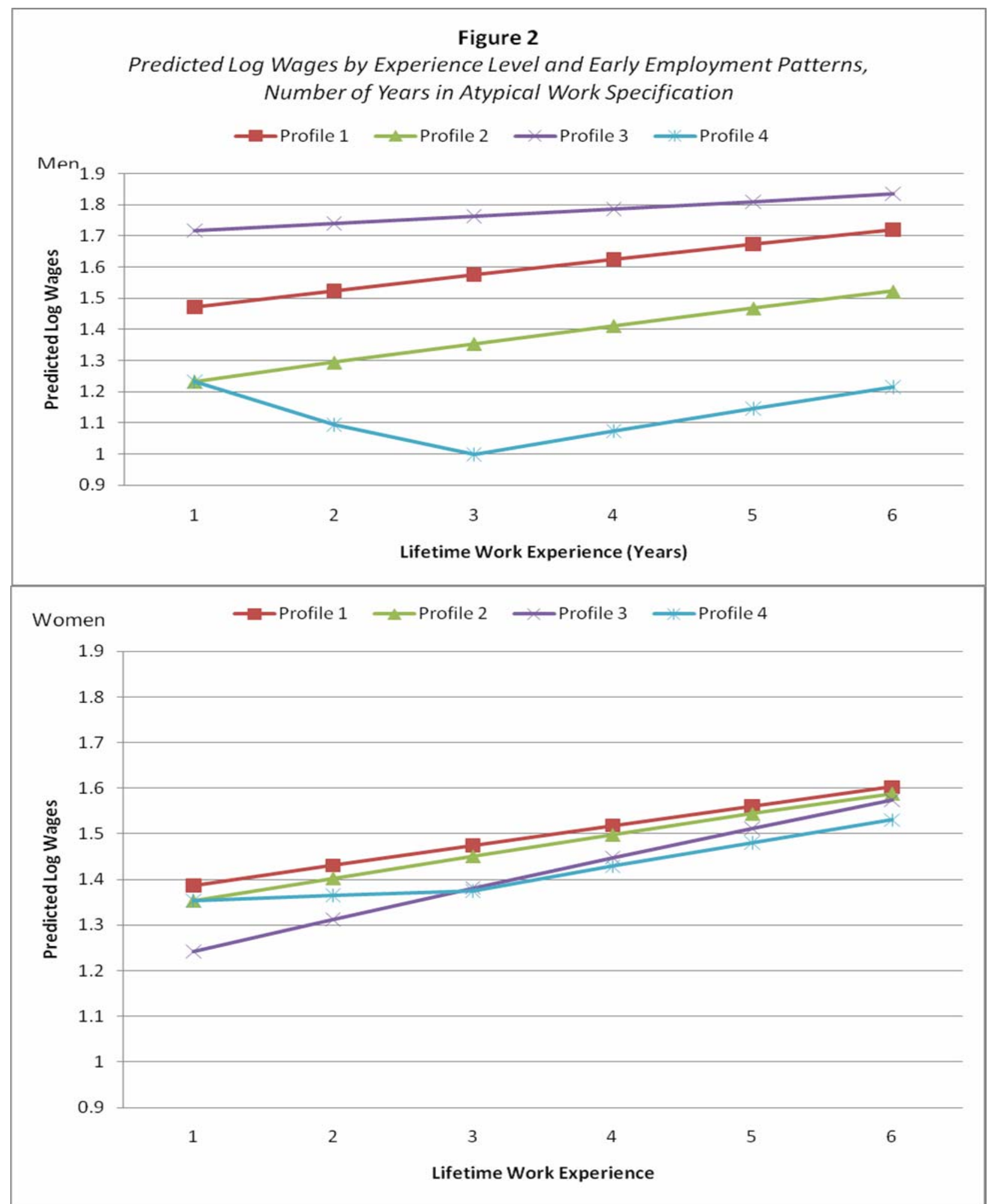

Notes: Predictions based on the estimates provided in Table 5. Pattern 1: Worker is always employed in a permanent job. Pattern 2: Worker employed as a temporary worker in first year and is employed in permanent employment thereafter. Pattern 3: Worker employed in contracting/consulting job in first year and is employed in permanent employment thereafter. Pattern 4: Worker holds three years of temporary employment and then is employed in permanent employment. 